DOI 10.31558/2617-0248.2021.6.11

УДК 338.43:504.64

\title{
ЕКОЛОГІЧНА БЕЗПЕКА ЯК ФУНДАМЕНТАЛЬНА СКЛАДОВА НАЦІОНАЛЬНОЇ БЕЗПЕКИ
}

ORCID ID: https://orcid.org/0000-0002-0295-5332

\section{Хилько М. І., Д. філос. н., професор Київського національного університету імені Тараса Шевченка}

Проаналізовано місце і роль екологічної безпеки в системі національної безпеки України. 3'ясовано, що екологічна компонента є надзвичайно важливим, та все ще мало усвідомленим складником національної безпеки, що гарантує захищеність життєво-важливих інтересів людини, суспільства, держави і природного довкілля від реальних чи потенційних загроз, що їх створює здебільшого сама людина. Це накладає відбиток на політичну, економічну, соціальну, духовну, інформаційну, воєнну та інші сфери життєдіяльності і врешті-решт на здоров'я людини. Тому українська держава не може бути ні демократичною, ні правовою, ні соціальною (про йдеться у Ст 1. Конституції України) якщо вона не буде екологічною, якщо не забезпечить первинні права людини на чисте повітря, чисту воду і продукти харчування.Ось чому екологічну безпеку слід розглядати не просто як складову національної безпеки, а як фундаментальну її складову і навіть більше - як інтегратора, який здатен консолідувати суспільство і забезпечити його прогресивний поступ.

Виявлені основні причини виникнення надзвичайних ситуацій, небезпек, загроз, техногенних аварій і катастроф в Україна за останні роки. Акцентується увага на зростанні масштабів екологічних загроз у віськово-промисловому комплексі, в хімічній, нафтохімічній галузі, агропромисловому комплексі. Зазначається про посилення синергетичного характеру дії небезпек.Визначено низку загроз національним інтересам в екологічній сфері.

Підсумовується, що при визначенні місця екологічного складника в системі національної безпеки важливий методологічний контекст полягає у стратегічному плануванні екологічної політики та визначенні особливостей формування відповідних прогностичних стратегій як складової цілісної системи національної безпеки на короткострокову та віддалену перспективу, що забезпечується системою організаційно-правових, економічних, технічних, санітарно-гігієнічних та інших заходів екологічного характеру.

Ключові слова: національна безпека, екологічна безпека, екологічні загрози, екологічна стратегія національний екологічний інтерес.

\section{Khylko M. I. Ecological security as a fundamental component of national security}

The place and role of ecological safety in the national security system of Ukraine are analyzed. It has been found that the environmental component is an extremely important, but still little understood, component of national security, which guarantees the protection of vital interests of man, society, the state and the natural environment from real or potential threats posed by man himself. This affects the political, economic, social, spiritual, informational, military and other spheres of life and ultimately human health. Therefore, the Ukrainian state can be neither democratic, nor legal, nor social (referred to in Article 1 of the Constitution of Ukraine) if it is not ecological, if it does not ensure the primary human rights to clean air, clean water and food. That is why environmental safety should be considered not just as a component of national security, but as a fundamental component of it and even more as an integrator who is able to consolidate society and ensure its progressive progress.

The main causes of emergencies, dangers, threats, man-made accidents and catastrophes in Ukraine in recent years have been identified. Emphasis is placed on the growth of the scale of environmental threats in the wax-industrial complex, in the chemical, petrochemical, agro-industrial complex. It is noted about strengthening of synergetic character of action of dangers. A number of threats to national interests in the ecological sphere are defined.

It is concluded that in determining the place of the environmental component in the national security system, an important methodological context is the strategic planning of environmental policy and determining the features of the formation of appropriate forecasting strategies as part of a holistic national security system in the short and long term. , sanitary and hygienic and other environmental measures.

Keywords: national security, ecological security, ecological threats, ecological strategy, national ecological interest. 
Щодо термінів. Існує безліч визначень і трактувань поняття «національна безпека». Так, політологічний словник визначає його як «явище, яке в сучасному загальному визначенні характеризує якісний стан властивостей системи «особистість - суспільство - держава - природа», що забезпечує гармонійну взаємодію складових і підтримання оптимальних умов іï існування і розвитку»[1, с.511]. Натомість у Законі України «Про основи національної безпеки України», цей термін вживається у такому значенні: «Національна безпека - це захищеність життєво важливих інтересів людини і громадянина, суспільства і держави, за якої забезпечуються сталий розвиток суспільства, своєчасне виявлення, запобігання і нейтралізація реальних та потенційних загроз національним інтересам»[2].

На наш погляд, національна безпека - це відсутність загроз правам і свободам людини, базовим цінностям суверенної держави, це спосіб самозбереження народу, який досяг рівня організації у формі незалежної держави Цей спосіб уможливлює його державно-організоване існування і вільний саморозвиток, надійний захист від зовнішніх і внутрішніх загроз. У такому розумінні національну безпеку України можна визначити як систему державно-правових та суспільних гарантій, що забезпечують стабільність життєдіяльності та розвитку державно-організованого народу України загалом, а також кожного громадянина держави окремо. Зауважимо, що безпека ніколи не буває повною і всеосяжною, безпека - це той рівень небезпек, з яким можна погодитись державі і суспільству в конкретно-історичних умовах, які не підривають стабільність життєдіяльності і його базаві цінності. У такому контексті, відповідно до пропозицій «Фонду національної міжнародної безпеки» національну безпеку слід визначати як систему державних та суспільних гарантій, що забезпечують стабільний розвиток нації, захист базових цінностей та інтересів, джерел духовного і матеріального добробуту від зовнішніх та внутрішніх ворогів.

Україна, як і будь-яка інша суверенна держава, вибудовує власну систему національної безпеки. Останнім часом для України ця проблема актуалізувалася як докорінними змінами базових цүінностей внутрішнього розвитку так $і$ змінами зовнішнього середовища. Зокрема:

1) трансформація соціально-економічної моделі розвитку від адміністративно-командної до ринкової і демократичної політичної системи;

2) позитивні і негативні наслідки впровадження запропонованих реформ;

3) демонтаж міжнародної й європейської систем безпеки;

4) агресивна політика Російської Федерації проти України (анексія Криму, ведення «гібридної війни» на Сході України, диверсії на всій території України, злобна антиукраїнська інформаційна пропаганда як серед населення Росії, України так і всого світового співтовариства з метою досягнення стратегії геополітичного реваншу «русского мира»;

5) претензії до України деяких політичних сил як на офіційному так і не на офіційному рівні (нерідко підбурювані Російською Федерацією) з приводу тих чи інших територій. Так, Польща претендує на частину Львівської і Волинської областей; Словакія на Прикарпатську Русь; Румунія на Бессарабію, Північну Буковину, Хотин, острів Зміїний; Росія вже окупувала Крим; висуває свої претензії й Угорщина;

6) зростання загроз глобального характеру (виснаження природних ресурсів, забруднення навколишнього середовища тощо).

Зазначене змушує постійно виявляти і своєчасно оцінювати реально існуючі і потенційні загрози безпеці України з метою визначення конкретних шляхів і засобів їх відвернення. Національна безпека України безпосередньо пов'язана з визначенням іiі національних інтересів, що віддзеркалюють вищі інтереси суспільства і громадянина. До пріоритетних інтересів України, згідно з Законом України "Стратегія національної безпеки України" належать:

- гарантування конституційних прав і свобод людини і громадянина;

- розвиток громадянського суспільства, його демократичних інститутів;

- захист державного суверенітету, територіальної цілісності та недоторканності державних кордонів, недопущення втручання у внутрішні справи України;

- зміцнення політичної і соціальної стабільності в суспільстві;

- забезпечення розвитку і функціонування української мови як державної в усіх сферах суспільного життя на всій території України, гарантування вільного розвитку, використання і захисту російської, інших мов національних меншин України;

- створення конкурентоспроможної, соціально орієнтованої ринкової економіки та забезпечення постійного зростання рівня життя і добробуту населення; розвитку;

- збереження та зміцнення науково-технологічного потенціалу, утвердження інноваційної моделі

- забезпечення екологічно та техногенно безпечних умов життєдіяльності громадян і суспільства, збереження навколишнього природного середовища та раціональне використання природних ресурсів;

- розвиток духовності, моральних засад, інтелектуального потенціалу Українського народу, зміцнення фізичного здоров'я нації, створення умов для розширеного відтворення населення;

- інтеграція України в європейський політичний, економічний, правовий простір та в євроатлантичний безпековий простір; розвиток рівноправних взаємовигідних відносин з іншими державами світу в інтересах України [3]. 
Із зазначено видно, що в концепції національної безпеки України важливе місце серед основних напрямків реалізації іiі інтересів, що здійснюються у різних сферах: політичній, економічній, соціальній, духовній, інформаційній, воєнній належить екологічній.

Екологічна безпека є компонентом національної безпеки, що гарантує захищеність життєво важливих інтересів людини, суспільства, держави та довкілля від реальних чи потенційних загроз, що їх створюють природні чи антропогенні чинники [4, с.64]. До того ж, екологічна складова кожного із зазначених видів безпеки може стати тим інтегратором, що об'єднає їх у систему національної безпеки, допоможе знайти їх оптимальне співвідношення в цій системі. Більше того, сьогодні вже не викликає сумніву, що будь-який аспект національної безпеки, будь-то економічний, технологічний чи оборонний втрачає свій сенс у разі непридатності довкілля для життя і діяльності людини. Ось чому екологічну безпеку слід розглядати не як одну із складових національної безпеки суспільства, а як інтегратор, який здатний, з одного боку, консолідувати суспільство, а з іншого - забезпечити його прогресивний поступ.

Дослідження екологічної безпеки у складі національної безпеки держави мають певну історію. Початок досліджень припадає на кінець XX століття, коли усвідомлення незалежності держави потребувало методологічного і методичного забезпечення формування політики національної безпеки, вивчення засад національної безпеки як системного багатокомпонентного явища й однієї з фундаментальних основ державотворення. Тому розгляд екологічної безпеки в сучасних реаліях формування національної стратегії $\mathrm{i}$ врівноваженої політики сталого економіко-екологічного розвитку вбачається актуальним науковим завданням.

Важливість дослідження екологічної безпеки в системі національної безпеки пов'язано з аналізом, попередженням та прогнозуванням надзвичайних ситуацій природного і техногенного характеру, що характеризуються постійним збільшенням матеріальних збитків і соціальних втрат. Ще наприкінці XX ст. людство втрачало в результаті аварій і катастроф 5-10\% сукупного валового продукту, тоді як його щорічний приріст становив лише $2-3 \%$.

На сьогодні характер надзвичайних ситуацій почав різко змінюватися, небезпеки і загрози стають тісніш взаємопов'язаними, дослідження їх дедалі більше переходить у міждисциплінарну площину. Ризик природних катастроф збільшується за рахунок антропогенної діяльності, яка є першопричиною багатьох природних катаклізм, що мали місце останнім часом. Так, катастрофічні повені у Закарпатті, неконтрольована вирубка лісів, зсуви у місцях видобування корисних копалин і місцях високої урбанізації. Феномен техногенної сейсмічності у багатьох країнах (найбільша з них сталася 12.11.2017 року на ірано-іракському кордоні з магнітудою 7,3, за шкалою Ріхтера, який забрав життя майже півтисячі осіб). В тому ж 2017 році землетрус з магнітудою у 5,7 бали стався в Азербайджані. Небезпека потужних розломів земної кори залишається і на українсько-румунському кордоні в так званій зоні Вранча, який за припущеннями фахівців перевищить потужність 1977 року (тоді в Бухаресті загинули 15 тис. людей). Масив українських та румунських Картат майже так само автивний як у Чілі і у Гаїті і може досягти 8-9 балів за 12-бальною шкалою Ріхтера. Нагадаю, що землетрус 1927 року силою у 8,0 балів зруйнував фактично все побережжя Криму (під час землетрусу море в буквальному сенсі вивертало у повітря півкілометрові стовпи полум'я. Так вибухав газ із підземних родовищ).

Усе це прямо чи опосередковано пов'язано з господарською діяльністю людини. Заразом, екологічна безпека $є$ проблемою транснаціональною і не може бути ефективно вирішена зусиллями лише однієї держави. Звідси - посилення ролі міжнародного співробітництва у цій сфері.

Останніми роками зростають масштаби екологічних небезпек, частіше виникають надзвичайні ситуації (причому здебільшого з вини людського фактору) на спеціальних об’єктах, зокрема атомної енергетики, найбільша з яких - аварія на Чорнобильській АЕС, Україна, 26.04.1986 р. (хоча початок подібного типу аварій увійшло в історію 12.12 .1952 р., як дата першої у світі аварії на атомній електростанції. Причиною стала помилка технічного характеру, яку допустив персонал АЕС Чолк-Рівер в штаті Онтаріо (Канада); далі була велика аварія на АЕС Віндскейл-Пайл (Великобританія, 10.10.1957 р.); у 1969 р. сталася аварія на АЕС Святий Лаврентій (Франція); 22.031975 р. в Алабамі (США); у 1979 р. на АЕС Айленд (США); 30.09 .1999 р. в Токамурі (Японія); 09.08.2004p. аварія на Аес Міхама на острові Хонсю(Японя).

На території України зберігається високий ризик виникнення надзвичайних ситуацій природного i техногенного характеру. Згідно Закону України «Про Основні засади (стратегію) державної екологічної політики України до 2030 року» в Україні функціонують 23767 потенційно небезпечних підприємств та інших об'єктів, аварії на кожному з яких можуть призвести до виникнення надзвичайних ситуацій техногенного і природного характеру державного, регіонального, місцевого та об'єктового рівня.

Щороку реєструється до 300 надзвичайних ситуацій природного і техногенного характеру, внаслідок яких гинуть люди, завдаються великі економічні збитки.

Основними причинами виникнення техногенних аварій $i$ катастроф та посилення негативного впливу внаслідок виникнення надзвичайних ситуацій природного і техногенного характеру в Україні є: застарілість основних фондів, зокрема природоохоронного призначення, великий обсяг транспортування, зберігання i використання небезпечних речовин, аварійний стан значної частини мереж комунального господарства, недостатня інвестиційна підтримка процесу впровадження новітніх ресурсозберігаючих і екологічно чистих технологій в екологічно небезпечних галузях промисловості, насамперед металургійній, хімічній, 
нафтохімічній та енергетиці; природоохоронні проблеми, пов’язані з істотними змінами стану геологічного та гідрогеологічного середовища та зумовлені закриттям нерентабельних гірничодобувних підприємств, шахт і розрізів, небажання суб'єктів господарювання здійснювати заходи із запобігання аваріям та катастрофам на об'єктах підвищеної небезпеки та потенційно небезпечних об'єктах тощо.

Зросли масштаби і кількість екологічних загроз і у військово-промисловому комплексі, в хімічній та нафтохімічній галузі тощо. Так, тільки за останні роки в Україні з вини людського фактора відбулося декілька надзвичайно небезпечних вибухів і пожеж на складах боєприпасів (26.09.2017 р. - с. Калинівка, Вінницької обл.; 23.03.2017. - м. Балаклія, Харківської обл.; 29.10.2015 р. - м. Сватове, Луганської обл.; 20.03.2014 р. - м. Кривий Ріг, Дніпропетровської обл.; 04.08.2008 - с. Лозове, Харківської обл.; тричі в с. Новобогданівка, Запорізької обл. - 06.15.2004 р.; 23.07.2005 p. і 19.08.2006 p.; 10.10.2003 р. - м. Артемівськ, Донецької обл. та ін., внаслідок яких загинули десятки людей, понівечені тисячі будинків і квартир, завдані мільярдні збитки). Значні загрози можуть виникнути і внаслідок зберігання потенційно небезпечних речовин, матеріалів, тимчасово законсервованих виробництв і технологій. 3'явилися й нові, нетрадиційні види небезпек - в інформаційній та медико-біологічній сферах, загострюється проблема тероризму та релігійного екстремізму тощо.

Водночас посилюється синергічний характер дії небезпек. Масштаб, тяжкість економічних і соціальних наслідків надзвичайних ситуацій дедалі більшою мірою визначаються не тільки перебігом подій, а й станом суспільства загалом. Системна криза економіки України значно поглибила потенційну ураженість господарських, соціальних об'єктів, знизила рівень захищеності населення і територій, а розв'язана Російською Федерацією війна проти України посилила втрати виробничої інфраструктури, призвела до виснаження фінансової сфери, погіршення стану довкілля, ресурсних та соціально-демографічних втрат та руйнування інфраструктури життєзабезпечення. Тому стратегія регіонального та загальнодержавного розвитку має спрямовувати організацію інфраструктури відповідно до новітніх викликів і вимог безпеки життєдіяльності.

Згідно з Законом України «Про стратегію національної безпеки України» національна безпека України забезпечується шляхом проведення виваженої державної політики відповідно до прийнятих доктрин, стратегій, концепцій і програм у таких сферах, як політична, економічна, соціальна, воєнна, екологічна, науково-технологічна, інформаційна тощо.

Конкретні засоби і шляхи забезпечення національної безпеки України обумовлюються пріоритетністю національних інтересів, необхідністю своєчасних заходів, адекватних характеру і масштабу загроз цим інтересам, і мають грунтуватися на правових засадах. Юридичне закріплення провідних норм взаємодії людини і природі в системі екологічного права $\epsilon$ основою їх легітимації та утворює правовий механізм екологічної безпеки. Основний закон України передбачає право кожного громадянина на безпечне для життя і здоров'я довкілля, закріплює за державою обов'язок у забезпеченні екологічної безпеки і підтриманні екологічної рівноваги на території України, подолання наслідків Чорнобильської катастрофи, збереження генофонду Українського народу, турбуватися про санітарно-епідемічне благополуччя громадян.

Законом України «Про стратегію національної безпеки України» визначено низку загроз національним інтересам в екологічній сфері. Ними є:

- надмірний антропогенний вплив і високий рівень техногенного навантаження на територію України;

- негативні екологічні наслідки Чорнобильської катастрофи;

- нераціональне, виснажливе використання мінерально-сировинних природних ресурсів;

- значний обсяг відходів виробництва та споживання i неналежний рівень їх вторинного використання, переробки та утилізації;

- незадовільний стан єдиної державної системи та сил цивільного захисту, системи моніторингу довкілля.

- зростання ризиків виникнення надзвичайних ситуацій техногенного та природного характеру;

- погіршення екологічного стану водних басейнів, загострення проблеми транскордонних забруднень та зниження якості води; загострення техногенного стану гідротехнічних споруд каскаду водосховищ на р. Дніпро;

- неконтрольоване ввезення в Україну екологічно небезпечних технологій, речовин, матеріалів і трансгенних рослин, збудників хвороб та ін.; небезпека техногенного та біологічного тероризму та ін. Згідно з екологічними загрозами Закон визначає і основні напрями державної політики з питань національної безпеки в екологічній сфері [3].

Екологічні загрози національній безпеці пов'язані зі значним антропогенним порушенням та техногенною перевантаженістю території України, негативними екологічними наслідками Чорнобильської катастрофи; неефективним використанням природних ресурсів, широкомасштабним застосуванням екологічно шкідливих та недосконалих технологій; неконтрольованим ввезенням в Україну екологічно небезпечних технологій, речовин і матеріалів; негативними екологічними наслідками оборонної та військової діяльності.

Україна, квітучий і благодатний у недалекому минулому край з оптимальними природними умовами і значним потенціалом рішенням Верховної Ради оголошено «зоною екологічного лиха». Економіка України, яка десятиліттями формувалася без урахування об’єктивних потреб та інтересів їі народу, належної оцінки 
екологічних можливостей окремих регіонів, стала однією з екологічно «найбрудніших», перенасичена хімічними, металургійними, гірничорудними виробництвами із застарілими технологіями. Абсолютна більшість промислових підприємств пов'язані головним чином з видобутком корисних копалин та початковими стадіями переробки сировини, тобто є нерентабельними, обтяжливими і забруднюючими. Матеріало-і енергоємність таких виробництв у декілька разів вище, ніж в індустріально розвинутих країнах. Отруйним тягарем на природу та населення України лягають ерозовані, пересичені пестицидами i отрутохімікатами землі і водойми, радіонуклідне випромінювання. Тому нема нічого дивного, що в Україні призупинилося природне відтворення населення - людей вмирає більше, ніж народжується, значно зросла народжуваність фізично та психічно неповноцінних дітей [5,c.141-143]..

Стає все очевидніше, що значне погіршення рівня і якості життя має окреслений екологічний контекст. Отже, для України ці проблеми є особливо актуальними. Розроблення й реалізація національної екологічної стратегії у контексті переходу нашої країни до моделі сталого розвитку відповідно до рішень Конференції ООН з навколишнього середовища і розвитку (Ріо-де-Жанейро, 1992), Всесвітнього саміту в Йоганнесбурзі (2002), політичних орієнтирів пан'європейського процесу «Довкілля для Свропи» та Глобальні цілі сталого розвитку до 2030 року, проголошені Генеральною Асамблеєю ООН від 25 ивересня 2015 року потребують екологізації суспільної свідомості, впровадження системи професійної екологічної підготовки, підвищення рівня екологічної освіти та культури, загалом проведення державної виваженої екологічної політики

Подолання екологічних загроз є складовою економічної політики держави та основним завданням політики екологічної. Субординація політик не має методологічно усталеної парадигми. I це вимагає певного екскурсу до методологічних проблем та засад визначення ролі і місця екологічної безпеки в системі національної безпеки у контексті забезпечення безпеки економічної. Так, у стратегічному сенсі економічну безпеку гарантує лише конкурентоспроможна економіка. Однак, держава практичним господарським управлінням переважно вирішує лише локальні завдання і досягає локальних цілей, що становлять повсякденну актуальність, і орієнтує на це всі вектори державної політики. Екологічна ж безпека має уможливлюватися саме через реалізацію стратегічних цілей (бо результативність екологічної політики визначається з часом) та потребує постійного державного піклування, передусім на інституційному рівні. Так, для здійснення екологічної політики на державному рівні потрібно достатньо усвідомлювати не лише екологічні проблеми, а й економічну можливість їхнього розв’язання.

Визначати цю економічну спроможність можна лише у контексті певних екологічних загроз та системи фінансування як окремих екологічних заходів, так і структури формування державного бюджету і ВВП країни загалом. Одним з показників, які використовуються міжнародною статистикою, є співвідношення активності держави у царині екологічної політики з певними значеннями розміру ВВП на душу населення на рік. Так, Японія розпочала активне впровадження екологічної політики при досягненні ВВП на душу населення на рівні 1600 дол. США, а Тайвань - 5500 дол., однак це не може слугувати дороговказом для України, бо рівень екологічних загроз і загострення екологічних проблем не допускають затримки у їх вирішенні, а свідомість українського суспільства вже цілком підготовлена до активізації екологічної політики [6, с.30].

Зважаючи на системний характер екологічних проблем, їх кореляцію 3 політичними, воєнними, економічними, технологічними та соціальними факторами, стратегія екологічної безпеки вбачається як одна з фундаментальних складових національної безпеки, національних цінностей й інтересів, де національні цінності- це матеріальні ідуховні об’єкти, ставлення до яких набуло визначального значення для самоусвідомлення та існування народу Україні. Це основа мотивації, саморозвитку народу України.

Національні інтереси - це усвідомлювані на рівні вищих органів державної влади потреби народу України узбереженні та розвитку національних цінностей. Залежно від характеру та сфери виявлення національні інтереси звично підрозділяють на: внутрішні й зовнішні, стратегічні й тактичні, постійні й тимчасові, політичні й економічні, соціальні й екологічні, воєнні тощо. Обстоювання національних інтересів України має своєю метою усунення або мінімізацію територіальних, демографічних, економічних, екологічних та інших втрат у процесі життєдіяльності їі народу.

Розглянемо, у чому ж полягає національний екологічний інтерес України. Національний екологічний інтерес Украӥни має постійний характер з певними особливостями на внутрішніх і зовнішніх векторах прояву.

Внутрішні національні інтереси відображають насамперед життєво важливі потреби існування і розвитку природи, людини, суспільства і держави, а зовнішні - умови їх збереження і розвитку. Так, зовнішній вектор прояву - це, зокрема, збереження біорізноманіття, зниження ризику виникнення надзвичайних ситуацій та оперативна ліквідація їх наслідків у разі виникнення. Внутрішній вектор обумовлений системою заходів зі збереження екологічної безпеки на рівні постійного моніторингу. Це стосується як раціонального використання природних ресурсів так і всього пов'язаного, зокрема, з утилізацією озброєння, використанням екологічно небезпечних речовин і технологій в оборонних цілях тощо. Означені вектори тісно пов'язані між собою, та все ж внутрішній вектор та внутрішня політика щодо екологічної безпеки $\epsilon$ визначальними у результативності й ефективності зовнішніх впливів.

Однак доцільно зазначити, що сучасна держава не спроможна самостійно долати наслідки найбільших природних і техногенних катастроф, скажімо рівня таких як Чорнобильська катастрофа. Каскад техногенних катастроф у слабо керованому суспільстві, природно, викликає занепокоєння світової спільноти, зокрема 
сусідів. Сучасна політика демонструє нам, що занепокоєння з приводу нестабільного державного управління викликає зовнішній вплив на керівництво країни, аж до воєнного. Тобто можна спрогнозувати, що у разі виникнення реальних небезпек на об'єктах підвищеного техногенного ризику та неспроможності держави долати ці небезпеки, тобто при відсутності ефективної екологічної політики, міжнародні структури й держави можуть встановити власний контроль за рівнем безпеки на відповідних об'єктах, а це межує 3 втратою політичного суверенітету.

Національний екологічний інтерес є фундаментальною (хоча все ще мало усвідомленою) цінністю суспільства, і піднесення його значення сприятиме поступальному розвиткові держави. Реалізація національного екологічного інтересу спирається на поєднання інтересів регіону, міста, об'єкта з інтересами держави та виконанням державою конституційних зобов'язань і міжнародних угод. Національний екологічний інтерес забезпечується державними інституціями і державною політикою органічної єдності гуманітарного, технологічного, соціально-економічного розвитку, політичної стабільності й піднесення добробуту населення. Фактично всім тим, що звертає суспільство до загальнолюдських цінностей, соціального захисту i гуманітарних пріоритетів.

На особливу увагу заслуговує вплив засобів масових комунікацій на усвідомлення й актуалізацію того чи іншого й особливо екологічного національного інтересу. Нерідко засоби масової інформації формують штучні уявлення про потреби й суспільні інтереси, які грунтуються суто на комерційних зисках певних компаній. Тому державне піклування за дотриманням національних інтересів та формування в суспільстві адекватного сприйняття національних пріоритетів $є$ безперечною прерогативою держави. У суспільстві, що тільки формується й не має чіткої ідентифікації, є можливість і конча потреба підвищити значення і цінність екологічних пріоритетів розвитку, сформувати екологічну соціальну потребу на рівні національного інтересу.

При визначенні місця екологічної безпеки в системі національної безпеки держави (вищий рівень національного інтересу) важливий аспект цього методологічного завдання полягає у вивченні стратегічного планування екологічної політики та визначенні особливостей формування відповідних прогнозованих стратегій як складової цілісної системи всебічного гарантування національної безпеки держави на середню та віддалену перспективу. Зазначимо, що в базовому Законі Украни з поліпшення екологічної ситуації та підвищення рівня екологічної безпеки «Про основні засади (стратегію) державної екологічної політики на період до 2030 року» [7] основними завданнями передбачено низку завдань по підвищенню рівня екологічної безпеки шляхом запровадження комплексного підходу до проведення оцінки ризиків, запобігання та мінімізації наслідків стихійних лих відповідно до Йоганнесбурзького плану дій та Глобальних цілей сталого розвику до 2030 року.

3 метою забезпечення національних інтересів України щодо сталого розвитку економіки, громадянського суспільства і держави, додержання конституційних прав і свобод людини і громадянина Президент України видав наказ «Про цілі сталого розвитку України на період до 2030 року», який включає виконання 17 пунктів, проголошених Генеральною Асамблеєю ООН від 25 вересня 2015 року № 70/1 та їх адаптації з урахуванням специфіки розвитку України[8].

Безперечно, створення ефективної дієвої, екологічно безпечної системи охорони довкілля - одне з найважливіших завдань для України. Залучення державних i приватних капіталовкладень на природоохоронні заходи при підвищенні рівня їх ефективності потребує запровадження нових інноваційних механізмів. I одним з головних пріоритетів в цьому ланцюзі є формування усуспільній свідомості уявлення про природу як естетичну й морально-етичну цінність, що передбачає формування високої екологічної культури як у представників влади так і у пересічних громадян, а це вимагає докорінної зміни системи екологічної освіти, просвіти, формування екологічних переконань, виваженої екологічної діяльності й своєчасного інформування населення щодо екологічних проектів тощо.

\section{Бібліографічний список:}

1. Політологічний словник: Навч. посіб. для студ. вищ. навч.закл. / За ред.. М.Ф. Головатого, та О.В. Антонюка. К.: МАУП, 2005. 792 с.

2. Закон України «Про основи національної безпеки України» Відомості Верховної Ради Украӥни. № 39. 26.09.2003.

3. Стратегія національної безпеки України. Указ Президента України від 26 травня 2015 року № 287/2015.

4. Екологічна енциклопедія: У 3-х т. / Редколегія: А.В. Толстоухов (головний редактор) та ін. К.: ТОВ «Центр екологічної освіти та інформації», 2006. Т.1. 432 с.

5. Хилько М.І. Екологізація політики. К.: ВАДЕКС, 2014. 344 с.

6. Яценко Л.Д. Екологічний складник національної безпеки: основні показники та способи їх досягнення: аналіт. доп. К.: НІСД, 2014. 52 с.

7. Закон України «Про Основні засади (стратегію) державної екологічної політики України на період до 2030 р. № 2697-VIII від 28.02.2019 р. Відомості Верховної Ради. 2019 № 16 ст. 70.

8. Указ Президента України «Про цілі сталого розвитку на період до 2030 року» № $722 / 2019$ від 30.09.2019 / zakon.rada.gov.ua. 
References:

1. Politolohichnyi slovnyk: Navch. posib. dlia stud. vyshch. navch.zakl. / Za red.. M.F. Holovatoho, ta O.V. Antoniuka. K.: MAUP, 2005. $792 \mathrm{~s}$.

2. Zakon Ukrainy «Pro osnovy natsionalnoi bezpeky Ukrainy» Vidomosti Verkhovnoi Rady Ukrainy. № 39. 26.09.2003

3. Stratehiia natsionalnoi bezpeky Ukrainy. Ukaz Prezydenta Ukrainy vid 26 travnia 2015 roku № 287/2015.

4. Ekolohichna entsyklopediia: U 3-kh t. / Redkolehiia: A.V. Tolstoukhov (holovnyi redaktor) ta in. K.: TOV «Tsentr ekolohichnoi osvity ta informatsii», 2006. T.1. $432 \mathrm{~s}$.

5. Khylko M.I. Ekolohizatsiia polityky. K.: VADEKS, 2014. $344 \mathrm{~s}$.

6. Iatsenko L.D. Ekolohichnyi skladnyk natsionalnoi bezpeky: osnovni pokaznyky ta sposoby yikh dosiahnennia: analit. dop. K.: NISD, 2014. $52 \mathrm{~s}$.

7. Zakon Ukrainy «Pro Osnovni zasady (stratehiiu) derzhavnoi ekolohichnoi polityky Ukrainy na period do 2030 r. № 2697-VIII vid 28.02.2019 r. Vidomosti Verkhovnoi Rady. 2019 № 16 st. 70.

8. Ukaz Prezydenta Ukrainy «Pro tsili staloho rozvytku na period do 2030 roku» № 722/2019 vid 30.09.2019 / zakon.rada.gov.ua.

DOI 10.31558/2617-0248.2021.6.12

УДК 323.173:32.01

\section{DEFINITION OF ETHNOPOLITICAL SEPARATISM AS A SOCIAL PHENOMENON}

ORCID ID: https://orcid.org/0000-0002-7739-7232

\section{Khevtsuriani Amiran, Doctor of International Relations, Professor at Georgian Technical University, Tbilisi, Georgia}

Currently, the entire world community is entering a new era, which is characterized by the emergence of numerous and widespread phenomena and challenges of world civilization, such as international terrorism, progressive nationalism, religious intolerance, as well as increasingly persistent political separatism. The disintegration of a number of political states in Asia, Africa and Europe, the destructive potential of disintegration of peoples that have existed for a long time within the framework of a single statehood, give grounds to believe that political separatism goes beyond the framework of not only national, but also regional security, acquiring an increasingly international aspect. These separatist movements use not only peaceful demonstrations in their arsenal, but violent forms such as uprisings also carry terrorist threats.

Extremist acts in this context represent a form of realizing a separatist goal, acquiring more and more new forms and methods. Certain political, nationalist, religious organizations of a separatist orientation use violent methods.

The current political situation shows that separatism becomes a tool and means of struggle for subjects of political activity in the process of achieving their goals. At the same time, it turned out to be profitable for political organizations, movements and individual politicians to use extremism.

Numerous cases of world disorder, irresponsible attitude to manifestations of political - national separatism led to the fact that at present separatism has acquired a large-scale and all-encompassing character, and political conflicts are extremely violent, acting as extremism and terrorism. It is argued a necessary prerequisite for the stability of a polyethnic state is a more or less homogeneous cultural space, a common political culture, a single ideological dominant. Achieving just such a state will, apparently, be the most effective means of preventing separatism in multinational states.

Keywords: Separatism; secession; irredentism; regionalism; nationalism; federalism.

Хевцуріані А. Визначення етнополітичного сепаратизму як суспільного явища

В даний час все світове співтовариство вступає в нову еру, що характеризується появою численних викликів світовій цивілізації, таких як міжнародний тероризм, прогресуючий націоналізм, релігійна нетерпимість, а також все більш стійкий політичний сепаратизм. Дезінтеграційні процеси в низці політичних держав Азії, Африки та Європи, руйнівний потенціал відокремлення народів, що існували протягом тривалого часу в рамках єдиних держав, дають підстави вважати, що політичний сепаратизм виходить за рамки не лише національної, але й регіональної безпеки, набуваючи все більше міжнародного аспекту. Сепаратистські рухи використовують не тільки мирні демонстрації, але й насильницькі форми, такі як повстання та терористична загроза. 